\title{
Analisis Implementasi Pernyataan Standar Akuntansi Keuangan (PSAK) 105 pada Pembiayaan Mudharabah
}

\section{Henny Triyana Hasibuan ${ }^{1}$ \\ Fakultas Ekonomi dan Bisnis Universitas Udayana, Indonesia}

\author{
Surel : henny_triyana@unud.ac.id
}

\section{ABSTRAK}

Tujuan dari penelitian ini adalah untuk menganalisis implementasi PAK 105 dalam pembiayaan mudharabah di PT Bank Muamalat Indonesia Cabang Denpasar pada tahun 2020. Metode penelitian yang digunakan adalah metode penelitian kualitatif. Hasil penelitian menunjukkan, proses pengakuan pada PT. Bank Muamalat Indonesia Tbk. Diadaptasi terhadap standar yang diterima secara umum, yaitu PSAK No. 105, Pengukuran investasi di PT. Bank Muamalat Indonesia Tbk. dalam bentuk tunai, diukur pada jumlah yang dibayarkan sesuai dengan PSAK 105, Penyajian pembiayaan mudharabah di PT. Bank Muamalat Indonesia Tbk. disajikan dalam neraca pada unsur aset sama dengan tagihan bank kepada pelanggan dan sesuai dengan PSAK 105, pembiayaan mudharabah diungkapkan oleh PT. Bank Muamalat Indonesia Tbk dalam laporan keuangan dan catatan atas laporan keuangan sesuai dengan PSAK 105.

Kata Kunci: Perlakuan Akuntansi; Pembiayaan Mudharabah; PSAK No. 105.

\section{Analysis of the Implementation of Statement of Financial Accounting Standards (PSAK) 105 on Mudharabah Financing}

\begin{abstract}
The purpose of this study was to analyze the implementation of PAK 105 in mudharabah financing at PT. Bank Muamalat Indonesia Denpasar Branch in 2020. The research method used was a qualitative research method. The results showed, The recognition process at PT. Bank Muamalat Indonesia Tbk. Adapted to generally accepted standards, namely PSAK No. 105, Measurement of investment in PT. Bank Muamalat Indonesia Tbk. in cash, measured at the amount paid in accordance with PSAK 105, Presentation of mudharabah financing at PT. Bank Muamalat Indonesia Tbk. presented in the balance sheet on the element of assets equal to bank bills to customers and in accordance with PSAK 105, mudharabah financing disclosed by PT. Bank Muamalat Indonesia Tbk in the financial statements and notes to the financial statements in accordance with PSAK 105.
\end{abstract}

Keywords: Accounting Treatment; Mudharabah Financing; PSAK No. 105.

Artikel dapat diakses : https://ojs.unud.ac.id/index.php/Akuntansi/index

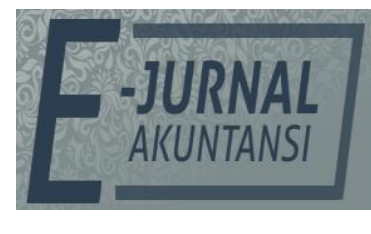

e-ISSN 2302-8556

Vol. 30 No. 12

Denpasar, Desember 2020

Hal. 3199-3208

DOI:

10.24843/EJA.2020.v30.i12.p16

PENGUTIPAN:

Hasibuan, H.T. (2020).

Analisis Implementasi

Pernyataan Standar

Akuntansi Keuangan

(PSAK) 105 pada

Pembiayaan Mudharabah.

E-Jurnal Akuntansi, 30(12),

3199-3208

RIWAYAT ARTIKEL:

Artikel Masuk:

21 Juni 2020

Artikel Diterima:

14 Desember 2020 


\section{PENDAHULUAN}

Tahun 2007 dapat dikatakan sebagai momentum kebangkitan ekonomi syariah. Situasi tersebut dijadikan momentum untuk menggerakkan sektor riil dan investasi. Pada saat ini lembaga keuangan tidak hanya melakukan kegiatan berupa pembiayaan investasi perusahaan, namun juga telah berkembang menjadi pembiayaan untuk sektor konsumsi, distribusi, modal kerja dan jasa lainnya (Ghozali, 2013) (Arthesa, 2006:7). Sepanjang sejarah bank-bank yang telah ada dan dirasakan mengalami kegagalan menjalankan fungsi utamanaya, yaitu menjembatani antara pemilik modal dengan pihak yang membutuhkan dana (Sumitro,2002:17).

Kegiatan bank syariah yang menghimpun dana dari masyarakat dan menyalurkannya kepada masyarakat, salah satu diantaranya adalah pembiayaan. Pembiayaan merupakan salah satu tulang punggung kegiatan di bank syariah. Terdapat berbagai jenis pembiayaan yang ada di bank syariah salah satu diantaranya adalah pembiayaan mudarabhah. Pembiayaan mudharabah merupakan salah satu produk pembiayaan bank syariah sebagai instrumen perekonomian dalam islam berdasarkan bagi hasil, dimana mudharabah secara tepat dipahami sebagai salah satu instrumen pengganti dari sistem bunga serta dapat diterapkan oleh lembaga keuangan syariah (Muhammad, 2005:101). Adapaun produk mudharabah sendiri merupakan produk berakad kerjasama dan berorientasi bisnis yang sumber dananya berasal dari dana pihak ketiga atau masyarakat dimana dana-dana ini dapat berbentuk giro, tabungan, atau simpanan deposito mudharabah dengan jangka waktu yang bervariasi, dana-dana yang sudah terkumpul ini disalurkan kembali oleh bank dalam bentuk pembiayaan-pembiayaan yang menghasilkan pendapatan aktiva (earning asset) dan keuntungan dari penyaluran pembiayaan inilah yang akan dibagi hasilkan antara bank dengan pemilik dana pihak ketiga (Karim, 2006:211).

Akad mudharabah merupakan akad kerjasama antara bank selaku pemilik dana dengan nasabah selaku mudharib yang mempunyai keahlian atau ketrampilan untuk mengelola suatu usaha yang produktif dan halal. Hasil keuntungan dari penggunaan dana tersebut dibagi bersama berdasarkan nisbah yang disepakati. Pembiayaan mudharabah dibangun dalam bentuk kerjasama Bank syariah sebagai shohibul maal yang menyalurkan dananya kepada nasabah sebagai mudharib dalam bentuk modal kerja sama yang mana keuntungannya didasarkan pada prinsip bagi hasil sehingga baik bank ataupun nasabah samasama mendapatkan keuntungan dan tidak ada yang merasa dirugikan dan seandainya dalam pelaksanaan usaha tidak memperoleh keuntungan maka baik nasabah ataupun bank akan sama-sama menanggungnya sehingga dalam pembiayaan ini prinsip keadilan bagi keduanya.

Bank sebagai shohibul maal (pemilik dana) bertugas sebagai fasilitator atau penyedia dana bagi nasabah yang ingin menjalankan usaha tetapi tidak memiliki dana, maka tugas bank sebagai penyalur dana membantu nasabah yang membutuhkan dana. Karim (2001), menyatakan bahwa hampir semua bank syariah di dunia didominasi dengan pembiayaan murabahah, sedangkan sistem bagi hasil sangat sedikit diterapkan, hal ini dipengaruhi oleh banyak faktor. Faktor ini dapat dikelompokkan menjadi dua yaitu: faktor internal perbankan syariah dan faktor eksternal bank syariah. Secara internal perbankan 
syariah mungkin belum dipahami secara baik oleh kalangan internal perbankan tentang mekanisme kerja produk mudharabah, pihak bank bersifat averse to risk (menghindari resiko) atas pembiayaan mudharabah. Sedangkan untuk faktor eksternal masih banyaknya masyarakat yang belum mengerti tentang produk mudharabah.

Pembiayaan mudharabah yang disalurkan oleh bank syariah kepada pihak lain untuk suatu usaha yang produktif bertujuan menghindari riba. Menurut istilah teknis, riba berarti pengambilan tambahan (premium) sebagai syarat yang harus dibayarkan oleh peminjam kepada pemberi pinjaman selain pinjaman pokok. Dalam hal ini, riba memiliki arti yang sama dengan bunga sebagaimana konsensus para fuqaha (Kuncoro2002:588). Antonio (2004) menjelaskan bahwa menurut Al-Quran, pandangan Islam mengenai riba dapat dilihat pada kutipan 4 surat dengan beberapa ayat, yang diturunkan dalam empat tahap berikut ini: Surat Ar- Rum ayat 39 menyatakan dan sesuatu riba (tambahan) yang kamu berikan agar dia bertambah pada harta manusia. Maka riba itu tidak menambah pada sisi Allah. Dan apa yang kamu berikan berupa zakat yang kamu maksudkan untuk mencapai keridhaan Allah, maka (yang berbuat demikian) itulah orang- orang yang melipatgandakan (pahalanya).

Secara teknis, Antonio (2001) mendefinisikan mudharabah sebagai akad kerja sama usaha antara dua pihak dimana pihak pertama (shahibul maal) menyediakan seluruh (100\%) modal, sedangkan pihak lainnya menjadi pengelola. Keuntungan usaha secara mudharabah dibagi menurut kesepakatan yang dituangkan dalam kontrak, sedangkan apabila rugi ditanggung oleh pemilik modal selama kerugian itu bukan akibat kelalaian si pengelola. Seandainya kerugian itu diakibatkan karena kecurangan ataskelalaian si pengelola, si pengelola haruss bertanggung jawab atas kerugian tersebut (Yaya, 2009:122).

Menurut PSAK No.105, perlakuan akuntansi atas pembiayaan mudharabah merupakan proses pembentukan suatu pos yang memenuhi definisi laporan keuangan serta kriteria pengakuan (ada kemungkinan manfaat ekonomi yang berkaitan dengan pos tersebut akan mengalir dari atau ke perusahaan dan pos tersebut mempunyai nilai atau biaya yang dapat diukur dengan andal. Pengakuan akuntansi dilakukan dengan menyatakan bahwa pos tersebut baik dalam kata-kata ataupun dalam bentuk rupiah serta mencantumkannya ke dalam neraca dan laporan laba rugi, sedangkan pengukuran merupakan proses penentuan jumlah rupiah untuk mengakui dan memperhiutnkannya ke dalam setiap elemen laporan keuangan yaitu neraca dan laporan laba rugi dengan mempergunaan dasar biaya historis, biaya terkini, nilai realisasi atau didasarkan pada nilai sekarang.

Hasil penelitian terdahulu menunjukkan bahwasanya masih banyak penyaluraan pembiayaan mudharabah oleh bank syariah yang belum sesuai dengan PSAK 105. Wahyu (2013) menyatakan masih terdapat ketidak sesuaian perlakuan akuntansi pembiayaan mudharabah dengan PSAK 105 dalam hal pengakuan keuntungan, pengungkapan akuntansidalam hal penyisihan kerugian invetasi mudharabah dan pengungkapan kerugian akibat penurunan nilai aset mudharabah. Irlanda (2017) menyatakan bahwa masih terdapat ketidak sesuaian perlakuan akuntansi pembiayaan mudharabah dengan PSAk 
105 dalam hal pengakuan dana yang disalurkan sebagai pembiayaan mudharabah.

Dibandingkan dengan bank konvesnsional, restukturisasi pembiayaan pada perbankan syariah masih lambat karena disebabkan oleh beberapa faktor. Faktor-faktor tersebut adalah kemampuan untuk membukukan pembiayaan dalam jumlah besar serta jumlah modal yang dimiki masih terbilang minim. Meningkatkan rasio pembiayaan macet pada bank syariah salah satu yang menjadi penyebab adalah penyaluran pembiayaan yang kurang berkembang. Standar Akuntansi yang mengatur tentang perlakuan akuntansi yang meliputi pengakuan, pengukuran, penyajian dan pengungkapan laporan keuangan atas transaksi mudharabah yang terdapat di dalam PSAK 105. PSAK 105 sebagai pedoman untuk menentukan apakah bank syariah telah menjalankan pembiayaan mudharabah sesuai dengan akuntansi syariah.

Berdasarkan latar belakang yang telah dipaparkan sebelumnya, maka peneliti tertarik untuk mengangkat pokok permasalahan yaitu bagaimana implementasi PSAK 105 terhadap pembiayaan mudharabah pada PT. Bank Muamalat Indonesia Tbk Cabang Denpasar dan apakah telah memenuhi ketentuan PSAK No. 105.

\section{METODE PENELITIAN}

Dalam penelitian ini digunakan jenis penelitian kualitatif dengan pendekatan deskriptif. Obyek penelitian ini adalah perlakuan akuntansi yang meliputi pengakuan, pengukuran, penyajian dan pengungkapan atas produk pembiayaan mudharabah dengan prinsip bagi hasil pada saat pencairan dana atau pembiayaan, pengembalian pembiayaan dari nasabah, biaya-biaya yang terjadi akibat pencairan pembiayaan, serta bagi hasil dan laba rugi yang terjadi di PT. Bank Muamalat Indonesia Tbk. Cabang Denpasar. Serta memahami konsep pembiayaan dalam prinsip mudharabah. Penelitian ini, adalah lapangan atau melakukan wawancara secara langsung pada bagian akuntansi pihak dari PT. Bank Muamalat Indonesia Tbk. Cabang Denpasar. Penelitian ini menggunakan metode observasi (Pengamatan).

\section{HASIL DAN PEMBAHASAN}

Pembiayaan mudharabah dibedakan menjadi dua, pembiayaan produktif dan pembiayaan konsumtif. Pembiayaan produktif yang digunakan untuk menambah modal atau membiayai sebuah proyek usaha. Sedangkan pembiayaan konsumtif diberikan untuk memenuhi kebutuhan yang akan langsung habis setelah kebutuhan terpenuhi.Dalam kaitannya dengan pembiayaan mudharabah ini, maka pembiayaan yang akan diberikan lebih bersifat produktif karena dalam pembiayaan ini nasabah (debitur) akan menggunakannya untuk kepentingan pengembangan usaha, seperti pertanian, perdagangan, industry, atau usaha-usaha yang brsifat kerajinan.

Untuk itu prosedur dan mekanisme yang ditetapkan bank dalam pengucuran dan pembiayaan mudharabah ini mempunyai syarat-syarat yang tidak saja bersifat adinistratif sebagaimana telah kita sebut diatas, tetapi juga terdapat ketentuan-ketentuan umum yang menjadi pedoman diberlakukannya pembiayaan mudharabah. Pedoman umum yang berkaitan dengan mekanisme 
pembiayaan mudharabah terdapat ketentuan-ketentuan umum yaitu, Semua orang baik nasabah atau bukan, berhak mendapat pembiayaan dari Bank Muamalat Indonesia asalkan memenuhi persyaratan diatas. Semua orang baik nasabah atau bukan, berhak menentukan besar kecilnya dana yang dibutuhkan. Ketentuan yang ada dalam bank menyebutkan bahwa batas maksimal pemberian kredit (BMPK) adalah 20\% dai modal dasar sebesar 400 juta maka BMPK yang diberikan kepada debitur sebesar 80 juta untuk setiapdebitur. Modal sepenuhnya dari bank dan pengelola usaha sepenuhnya ditangani oleh pengelola tanpa campur tangan dari bank. Oleh karena itu sebagai seorang pengelola yang telahmengeluarkan tenaga, pikiran dan waktunya, bank menetapkan bagi hasil yang lebih besar dari dirinya.

Untuk pembiayaan yang berskala besar ditetapkan adanya jaminan yang besarnya $125 \%$ dari besarnya jumlah dana yang akan dipinjam. Jangka waktu ditetapkan dalam tenggang waktu yang pendek. Ini ditetapkan khusus bagi nasabah yang belum terakreditasi kejujurannya. Ketetapan batas pendek masa peminjaman ini adalah dalam rangka mencoba prospektifitas usaha nasabah di samping untuk mengukur sifat kejujurannya. Nasabah diharuskan membayar angsuran setiap bulan sepanjang waktu yang disepakati, atau pada saat ijab dan qobul. Besarnya cicilan tidak secara tetap ditentukan oleh bank, tetapi cicilan tersebut harus selesai pada waktu yang telah disepakati. Bank Muamalat Indonesia akan memberikan potongan pada pelunasan sebelmwaktunya.

Setiap penyaluran dana kepada nasabah, bank menindak lanjuti dengan pembinaan nasabah yang bersangkutan, sehingga padawaktunya nanti dapat melunasi hutangnya kepada bank. Peminjam yang diberikan bank bukan merupakan uang tunai, tetapi merupakan dana untuk pengadaan barang/jasa yang diikat dengan perjanjian kredit. Karena dalam sistem mudharabah biaya dibebankan dalam bentuk bagi hasil yang diperhitungkan melalui prinsip kemanfaatan barang/modal yang dibiayaibank. Perjanjian bagi hasil mulai diberlakukan secara efektif setelah proyek investasinya selesai sesuai dengan jangka waktu yang telah disepakati. Pada saat itu bank dan nasabah bersamasama menghitung porsi bagian laba masing-masing. Bila terjadi kerugian maka bank akan menanggung kerugian tersebut. Peminjam hendaknya merencanakan terlebih dahulu secara matang tentang usaha, tempat, lokasi, pasar, dan jumah biaya yangdibutuhkan. Dari pihak bank perku mengadakan observasi terhadap semua rencana usaha yang akan dilakukan nasabah. Peminjam perlu mempelajari adminstrasi praktis tentang pengelolaan usaha yang sedang ditekuninya sehingga keterbukaan dan kejujuran dapat terbaca oleh pihak bank. Adapaun kebijakan akuntansi yang diterapkan PT Bank Mualamat Indonesia Tbk Cabang Denpasar adalah, Pernyataan Kepatuhan, dan Penyajian Laporan Keuangan.

Pernyataan kepatuhan laporan keuangan disusun sesuai dengan Standar Akuntansi Keuangan di Indonesia. Penyusunan laporan keuangan telah sesuai dengan Pernyataan Standar Akuntansi Keuangan No. 101 tentang Penyajian Laporan Keuangan Syariah, PSAK 102. Akuntansi Murabahah, PSAK 104, Akuntansi Istihsna, PSAK No. 105, Akuntansi Mudharabah, PSAK No. 106, Akuntansi Musyarakah, PSAK No. 107, Akuntansi Ijarah, Pedoman Akuntansi Perbankan Syariah Indonesia (PAPSI), Peraturan Badan Pengawas Pasar Modal 
dan Lembaga Keuangan (BAPEPAM-LK) dan Pedoman Penyajian laporan Keuangan bagi Bank yang menawarkan sahamnya pada masyarakat.

Penyajian laporan kuangan, kecuali untuk laporan arus kas penyusunannya berdasarkan metode akrual. Mata uang pelaporan yang digunakan untuk penyusunan laporan kuangan adalah mata uang rupiah dan laporan keuangan tersebut disusun berdasarkan nilai historis. Laporan arus kas disusun dengan menggunakan metode langsung yang dimodifikasi yaitu mengungkapkan penerimaan kas bruto dan pengeluaran kas bruto untuk beberapa aktivitas operasi, investasi dan pendanaan. Penyajian laporan arus kas, kas dan setara kas terdiri dari kas, giro pada Bank Indonesia, giro pada bank lain dan Sertifikat bank Indonesia yang jatuh tempo dalam waktu tigabulanatau kurang dari tanggal perolehannya dan yang tidak dibatasi penggunannya.

Adapun pembahasan yang bersumber dari informan yaitu Bapak Haris selaku HRD Manajer, menjelaskan bahwa di dalam bank muamalat terdapat dua produk yang saling terkait yaitu produk pendanaan dan produk pembiayaan. Asumsikan produk pendanaan adalah tabungan mudharabah, dimana didalam produk ini nasabah akan menyetorkan sejumlah uang kepada bank. Setelah bank mendapatkan dana dari nasabah maka dana ini akan kita alokasikan kepada produk pembiayaan. Asumsikan lagi bahwa produk pembiayaan ini adalah sistem bagi hasil mudharabah, dalam produk pembiayaan ini bank akan memilih atau menunjuk nasabah untuk dibiayai, atau dalam kata lain bank akan berinvestasi dengan dana dari nasabah produk pendanaan yaitu nasabah tabungan mudharabah. Dari investasi ini, bank akan mendapatan keuntungan dari proses bagi hasil mudharabah. Setelah berakhirnya proses bagi hasil atau jatuh tempo, maka dana yang digunakan oleh bank sebagai dana pembiayaan mudharabah tadi akan dikembalikan kepada nasabah tabungan mudharabah.

Pembiayaan Mudharabah sendiri adalah akad kerjasama usaha antara Bank sebagai pemilik dana (shahibul maal) dan nasabah sebagai pengelola dana (mudharib) untuk melakukan kegiatan usaha dengan nisbah pembagian hasil (keuntungan atau kerugian) menurut kesepakatan dimuka. Menurut informan standard dan juga pedoman yang digunakan terkait dengan pencatatan transaksi dan penyusunan laporan keuangan adalah standar yang telah ditetapkan oleh IAI yaitu PSAK, dan juga PAPSI 2003.

Terkait dengan produk mudharabah yang ada di PT. Bank Muamalat Indonesia Tbk adalah mudharabah muthlaqah dan mudharabah muqayyadah. Perlu diketahui bahwa PT. Bank Muamalat Indonesia Tbk. belum pernah menerapakan produk gabungan antara mudharabah muthlaqah dan muqayyadah atau dengan kata lain adalah mudharabah musytharakah. Jadi produk mudharabah yang digunakan oleh PT. Bank Muamalat Indonesia Tbk, hanya dua jenis yaitu mudharabah muthlaqah dan muqayyadah. Dua jenis produk pembiayaan yaitu mudharabah muthlaqah dan mudharabah muqayyadah kedua jenis pembiayaan tersebut tidak ada yang dibawah satu tahu, pembiayaan-pembiayaan ini minimal tigatahun.

Adapun data-data yang mendukung terjadinya sebuah akad mudharabah adalah rukun dalam akad, rukun disini merupakan suatu hal yang harus ada pada akad mudharabah. Bapak Haris menjelaskan salah satu rukun 
yang wajib ada pada syarat pembiayaan mudharabah di sini adalah usaha atau proyek yang akan di bentuk, bila usaha atau proyek tersebut telah sah, atau dengan kata lain bank telah menyetujui dengan usaha atau proyek tersebut, maka pembiayaan mudharabah dapat dilaksanakan antara keduabelah pihak baik itu antara bank dengan nasabah (mudharib). Dari hal ini, dalam hal penggunaan akad atau penerapan akad dapat menyimpulkan bahwa PT. Bank Muamalat Indonesia Tbk Cabang Denpasar telah menerapkan PSAK No. 105 tentang akuntansimudharabah.

Pada proses kesepakatan di awal meskipun bank sebagai pemilik dana(shahibul maal) telah menerapkan prinsip kehati-hatian dalam menilai dan memilih kelayakan nasabah yang akan menjadi pengelola dana (mudharib), bank akan meminta jaminan sebagai wujud penjaminan atas pengelola dana agar tidak melanggar perjanjian yang telah disepakati, jadi jaminan tersebut sebagai bentuk keseriusan mudharib dalam melakukan penjaminan guna untuk modal usaha.

Sebagaimana telah tertera pada PSAK No.105 bahwa Pada prinsipnya dalam penyaluran mudharabah tidak ada jaminan, namun agar pengelola dana tidak melakukan penyimpangan maka pemilik dana dapat meminta jaminan dari pengelola dana atau pihak ketiga. Jaminan ini hanya dapat dicairkan apabila pengelola dana terbukti melakukan pelanggaran terhadap hal-hal yang telah disepakati bersama dalam akad. Untuk proses selanjutnya setelah bank sebagai pemilik dana (shahibul maal) dan juga pengelola dana (mudharib) telah menyetujui proses kesepakatan awal, maka selanjutnya adalah proses pencairandana.BapakHaris menjelaskan bahwa dana yang disalurkan oleh PT. Bank Muamalat Indonesia Tbk. (shahibul maal) kepada nasabah pengelola dana (mudharib) akan diakui sebagai investasi pada pembiayaan mudharabah pada saat dana tersebut diberikan atau dibayarkan kepada pengelola dana (mudharib). Baik pemberian secara tunai maupun pemberian dengan cara droping secara langsung ke rekening nasabah. Dari pengakuan PT. Bank Muamalat Indonesia Tbk. terhadap penyaluran dana, peneliti dapat menyimpulkan bahwa pengakuan tersebut telah sesuai dengn aturan PSAK No. 105 tentang akuntansi mudharabah.

Setelah pengelola dana (mudharib) menerima dana syirkah temporer, pada saat itu pula bank akan memonitoring setiap bulannya guna mengawasi berjalannyasebuah akad dengan baik dan agar tidak terjadi penyalahgunaan terhadap dana yang telah diberikan. Peneliti dapat menyimpulkan bahwa "usaha mudharabah dianggap mulai berjalan sejak dana atau modal usaha mudharabah diterima oleh pengelola dana". Hal tersebut talah sesuai dengan PSAK No. 105. Apabila setelah usaha berjalan dan usaha tersebut mengalami kerugian yang bukan disebabkan oleh pengelola dana akan tetapi sebab bencana alam atau dikarenakan faktor perekonomian maka bank akan melakukan penyelamatan apabila usaha tersebut dalam jangka waktu kedepan masih dapat membaik, namun bila dalam pandangan pemilik dana (shahibul maal) usaha tersebut tidak dapat membaik untuk jangka waktu kedepan, maka akan tetap dibagihasilkan.

Terkait dengan penyajian yang dilakukan oleh PT. Bank Muamalat Indonesia Tbk. selaku pemilik dana. PT Bank Muamalat Indonesia Tbk. 
menyajikan pembiayaan mudharabah dalam laporan keuangan yang sesuai berdasarkan nilai yang tercatat. Nilai tercatat yang ada di PT. Bank Muamalat Indonesia Tbk adalah nilai yang terjadi selama periode yang ada yaitu dana awal investasi mudharabah pada tahun yang sebelumnya ditambahkan dengan jumlah investasi mudharabah yang terjadi, dan selanjutnya harus dilakukan penyisihan penghapusan untuk penghapusukuan agar tidak ada piutang yang menunggak yang tertagih. Pencatatan penyisihan penghapusan disajikan didalam laporan keuangan yaitu dana syirkah temprer dari pemilik dana disajikan sebesar nilai tercatat, begitu juga dengan bagi hasil dana syirkah temporer yan telah diperhitungakan tetapi belum diserahkan kepada pemilik dana di PT. Bank Muamalat Indonesia Tbk.

Pengungkapan laporan keuangan yang dilakukan oleh PT. Bank Muamalat Indonesia Tbk Cabang Denpasar, sebagai pemilik dana, harus mengungkapkan isi kesepakatan utama usaha mudharabah seperti porsi dana, pembagian hasil usaha, aktivitas usahamudharabah dan lain-lainnya. PT. Bank Muamalat Indonesia Tbk telah menerapkan aturan PSAK No. 105 di dalam akad pembiayaan mudharabah. Akad merupakan perjanjian antara nasabah dengan pemilik dana atau bank. Didalam kesepakatan dalam membuat akad, yang terpenting adalah perhitungan aktivitas usaha dan proyeksi realisasi pendapatan bagi hasil. Rincian jumlah investasi mudharabah berdasarkan jenisnya telah disesuaikan dengan PSAK No. 105 telah tercantum didalam laporan keuangan berdasarkan mudharabah muthlaqah dan muqayyadah. Penyisihan kerugian investasi mudharabah selama satu periode berjalan telah diungkapkan didalam catatan atas laporan keuangan, setiap tahun PT. Bank Muamalat Indonesia Tbk. melaporkan jenis mudharabah, dan menunjukkan penyisihan penghapusan.

\section{SIMPULAN}

Penelitian ini bertujuan untuk mengetahui perlakuan akuntansi pembiayaan mudharabah berdasarkan PSAK No. 105 tentang akuntansi pembiayaan mudharabah pada PT. Bank Muamalat Indonesia Tbk. cabang Denpasar, dengan kesimpulan sebagai berikut, Proses pengakuan pada PT. Bank Muamalat Indonesia Tbk. telah disesuaikan dengan standar yang telah berlaku umum yaitu PSAK No. 105 pada saat penyaluran dana oleh bank sebagai pemilik dana (shahigul maal) kepada nasabah pengelola dana (mudharib) dilakukan berdasarkan kesepakatan yang ada di akad, dimana kesepakatan tersebut dibuat oleh bank yang menjadi pemilik dana dan nasabah pengelola dana. Pengukuran pembiayaan pada PT. Bank Muamalat Indonesia Tbk Cabang Denpasar dalam bentuk kas diukur sebesar jumlah yang telahdibayarkan, yaitu pada saat nasabah melakukan pembayaran pokok pinjaman, pembayaran tersebut dapat dilakukan secara bertahap maupun pada saat akhir perjanjian,apabila nasabah melakukan pembayaran pokok dengan tahap pembayaran setiap bulannya, maka nasabah juga harus menyisipkan pembayaran nisbah bagi hasil setiap bulannya. Penyajian pembiayaan mudharabah pada PT. Bank Muamalat Indonesia Tbk Cabang Denpasar disajikan didalam neraca pada unsur aktiva sebesar tagihan bank kepada nasabah. Penyajian yang dilakukan oleh pemilik 
dana yaitu menyajikan investasi mudharabah dalam laporan keuangan yang sesuai berdasarkan nilai yang tercatat.

Nilai tercatat merupakan nilai yang terjadi selama periode yang ada yaitu dana awal investasi mudharabah pada tahun yang sebelumnya ditambah dengan jumlah investasi mudharabah yang terjadi, selanjutnya harus dilakukan penyisihan penghapusan. Hal tersebut telah sesuai dengan PSAK No. 105 tentang akuntansi mudharabah, karena bagi hasil yang sudah diperhitungkan dan yang belum diserahkan harus tetap disajikan dilaporan dana syirkah temporer. Pengungkapan pembiayaan mudharabah diungkapkan oleh PT.BankMuamalat Indonesia Tbk Cabang Denpasar didalam laporan keuangan dan catatan atas laporan keuangan. Dimulai dari jenis akad, rincian dana syirkah, penyaluran dana yang diterima,dan penyajian laporan keuangan diungkapkan dalam catatan atas laporan keuangan. Hal tersebut telah sesuai dengan PSAK No. 105. Diharapkan pada penelitian selanjutnya, peneliti selanjutnya dapat melihat secara langsung dari sisi nasabah, sehingga dapat diketahui apakah yang membuat nasabah tertarik untuk melakukan akad pembiayaan mudharabah, bagaimana keuntungan dalam proses bagi hasil.

\section{REFERENSI}

Antonio, M. S. (2004). Bank Syariah dari Teori Praktik, 2004 yang dikutip dari M.Rawas Qal"aji,mu'jam lughat al-fiqaha. (Beirut: darun-nafis,1985)

Arthesa, A. (2006). Bank dan Lembaga Keuangan bukan Bank. Jakarta: PT.Indeks Kelompok Gramedia.

Burhan, B. (2007). "Penelitian Kualitatif". Jakarta : Prenada Media Group

Dewan Syariah Nasional (DSN). (2003). Himpunan Fatwa Dewan Syariah Nasional. Jakarta: Dewan Syariah Nasional.

Fatwa Dewan Syariah Nasional No: 07/DSN-MUI/2000 Tentang Pembiayaan Mudharabah (Qiradh)

Harahap, S. S. (2001). Menuju Suatu Teori Akuntansi Islam. Jakarta: Pustaka Quantum.

Harahap, S. S. (2002). Akuntansi Perbankan Syariah. (EdisiPertama. Jakarta: LPFE Usakti

Ikatan Akuntan Indonesia. (2009). Pernyataan Standar Akuntansi Keuangan, No. 105. Jakarta : Salemba Empat.

Karim A. A. (2006). Bank Islam Analisis Fiqih dan Keuangan. PT. Raja Grafindo Persada, Jakarta

Kuncoro, M. \& Suhardjono. (2002). Manajemen Perbankan, Teori dan Aplikasi. BPFE, Yogyakarta.

Irlanda, M. O. (2017). Analisis Penerapan PSAK 105 Atas Pembiayaan Mudharabah Pada BPRS Bangun Drajat Warga dan BPRS Madina Mandiri Sejahtera Yokyakarta

Mohamed S, Syed Alwi. (2008). Accounting For islamic Financial Product. Kuala Lumpur: CERT Publications

Muhammad. R. (2008). Akuntansi Keungan Syariah : Konsep dan Implementasi PSAK Syariah. Yogyakarta: P3EI Press

Muhammad. (2002). Bank Syariah "Analisis, Kekuatan, Kelemahan, Peluang, dan Ancaman. EKONISA, Yogyakarta. 
Muhammad. (2005). Manajemen Pembiayaan Bank Syariah. UPP AMP YKPN, Yogyakarta.

Muslehudin, M. (2004). Sistem Perbankan Dalam Islam. Jakarta : PT Rineka Cipta

Nur H. (2002). Urgensi Laporan Keuangan (Akuntansi Syari'ah) dalam Praktek Ekonomi Islam,Simposium Nasional I Sistem Ekonomi Islami. Yogyakarta: P3EI FE UII,2002

Riza, S. dan Riza, K. (2012). Akuntansi perbangkan Syariah Berbasis PSAK Syariah. Padang: Akademia Permata

Sabiq, S. (2006). Figh Sunnah. Penerjemah: Nor Hassanuddin. Diterjemahkan dari kitab Fiqhus Sunnah. Lebak Bulus: Pena Pundi Aksara.

Sahrani, S . (2011). Fikih Muamalah. Bogor: Ghalia Indonesia

Sarwono, J. (2006). Metode Penelitian Kuantitatif dan kualitatif. Yogyakarta: Graha Ilmu.

Shahatan, H. (2001). Usul al-Fikr al-Muhasab al-Islami (terjemahan). Jakarta: Akbar Media Sarana

Soejono. (1999). Metode Penelitian Suatu Pemikiran dan Penerapan. Pustaka LP3ES Indonesia, Jakarta.

Suminto.Warkum. (2004). Asas-Asas Perbankan Islam. Jakarta: PT Raja Grafindo Persada.

Sumitro, W. (2002). Asas-Asas Perbankan Islam dan Lembaga- Lembaga Terkait (BMI dan TAFAKUL di Indonesia). Jakarta: PT. Syahdeni.

Sutan, R. (1999). Perbankan Islam dan Kedudukannya Dalam Tata Hukum Perbankan Indonesia. Jakarta: PT. Pustaka Utama

Wiroso, M. Y. (2010). Akuntansi Perbangkan Syariah PSAK Syariah Baru. Jakarta; LPEE Usakti

Yaya, R. \& Martawireja, A. E. (2009). Akuntansi Perbankan Syariah Teori dan Praktik Kontemporer. Jakarta: Salemba Empat

Wahyu, A. K. (2013). Analisis Penerapan Akuntansi Pembiayaan Mudharabah dengan Psak No 59 dan PSAK 105 pada KJKS-BMT Bina Umat Sejahtera. Yokyakarta.

Zainuddin, M. (2008). Metodologi Penelitian Pendekatan Praktis dan Aplikatif. Refika Aditama, Bandung. 